QL
596
PEF

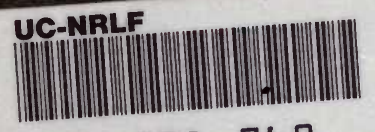

B 3371760 


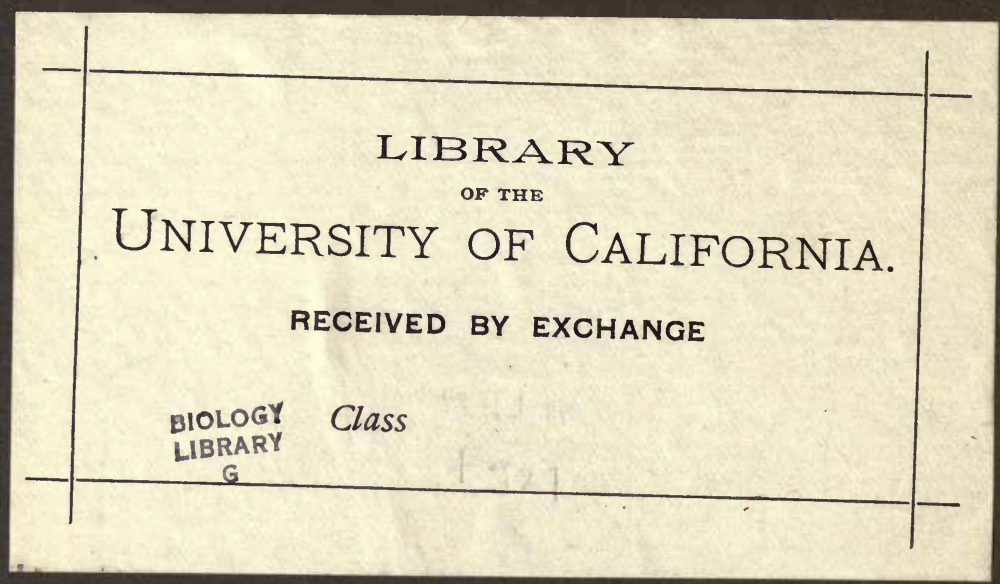


TECHNICAL 'EDUCATION SERIES, NO. 8.

DEPARTMENT OF PUBLIC INSTRUCTION. TECHNICAL EDUCATION BRANCH.-F. BRIDGES, Superintendent.

\section{TECHNOLOGICAL MUSEUM.}

REPORT

ON A

\section{BEETLE DESTROYING BOOTS \& SHOES}

\section{IN SYDNEY :}

BY WALTER W. FROGGATT.

(With one plate.)

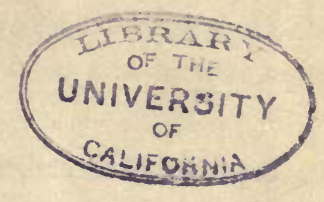

J. H. MAIDEN, F.L.S., \&c., Curator.

SYDNEY :

GEORGE STEPHEN CHAPMAN, ACTING GOVERNMENT PRINTER. $5 a^{*} 240-91$ $\overline{1891 .}$ 


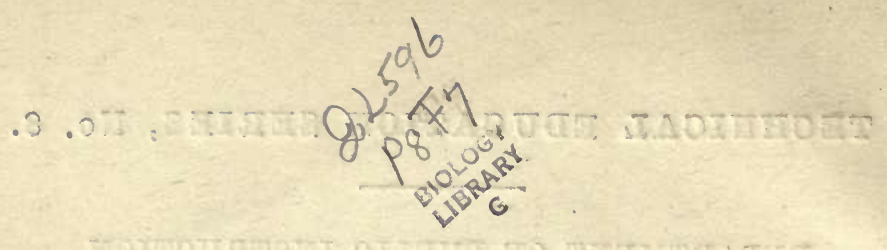

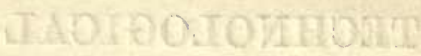

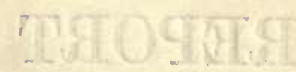

\section{EXPLANATION OF PLATE.}

\section{LIFE HISTORY oF Anobium paniceum, LINN.}

Fig. i. Perfect beetle (enlarged). Fig. ia. Jaws of beetle. Fig. ib. Side view of head of beetle.

Fig. ii. Larva when full grown.

Fig. iii. Pupa.

Fig. iv. Parasitic Wasp (family Chalcidida) living on the pupa of Anobium.

All these specimens were taken out of infested boots, and drawn under the microscope. The lines beside figures show the natural size. 


\section{REPORT ON A BEETLE DESTROYING BOOTS AND SHOES IN A SYDNEY WaREHOUȘE,}

To the Curator of the

Technologicat Musedu, Sydney.

Acting under your instructions, on the 7 th October I visited the warehouse reported to you, to obtain specimens and all information about a beetle said to be infesting some trunks of imported boots, and damaging the contents.

I examined five infested trunks of various qualities of boots and shoes ; ordinary men's leather boots, ladies' kids, and carpet slippers were all attacked in a similar manner.

The chief point of assault seems to be the soles, which are often completely riddled with small transverse and vertical burrows made by the larvæ of these insects. Another favourite place of abode is in the tips of the uppers, but some samples showed signs of their handiwork everywhere.

They were first noticed in the sample bins, where the samples used by the firm's travellers were kept when returned, and were thought to have been introduced into the warehouse in these boots, until further investigation showed that there were infested trunks in other parts of the building.

As far as is yet known, all the damaged goods are of English manufacture, none of those imported from continental houses showing signs of these pests.

As the eggs and larvæ of many beetles under normal surroundings often take a considerable time to come to maturity, it is quite possible that these came into the boot-trunks in the egg or larval state, either in the finished leather or in some of the material used in making up the boots, and since undisturbed have there undergone their metamorphoses.

I obtained a large number of specimens of the beetles, the active larvæ, and the quiescent pupæ, together with several 
specimens of a minute four-winged fly, a hymenopterous insect, belonging to the family Chalcidida, evidently parasitic upon the pupa of the beetle.

Upon examination I found the beetle to be a member of the family Ptinide, coming in the genus Anobium, agreeing in all particulars with Anobium paniceum, Linn., a common English species.

All the Ptinida are of small size, few exceeding $\frac{1}{4}$ of an inch in length, and most of them are much smaller; they have cylindrical bodies, with the head small and partially hidden under the thorax; they are widely dispersed over the temperate parts of the world, and though many described species of allied genera are described from Australia, none belonging to Anobium are indigenous.

Over sixty species of Anobium are described from Europe alone. They are so much alike in size and color, while the older entomologists gave such brief descriptions of the earlier described species, that it is a matter of great difficulty to satisfactorily identify an introduced specimen without some type specimens for reference.

This family contains some of the most destructive and omnivorous feeders among the beetle family. Many of them live in wood, others frequent houses, where they attack dried skins, wool, leather, \&c. Anobium domesticum, Foure, is common in the wood-work and furniture of old houses, where it is well known under the popular name of the "death watch." Kirby, in his "Text Book of Entomology," says that they are known to at leather, but I can find no record of them having attacked manufactured leather in the wholesale manner that they have in the present instance.

However, Anobium paniceum is recorded to have tried his sharp little jaws upon almost everything. Curtis says he has known it to eat and pupate in cayenne pepper, completely destroying the contents of the tins, that it is a pest in drugstores, eating all kinds of dried roots, and that among ship- 
owners it is well known for the ravages it commits in the ship biscuits, eating and breeding in them until they are utterly destroyed.

He also says that he has been informed that they were very plentiful in the roof of King's College Chapel, Cambridge, where they were reported to have eaten through the sheet lead.

In 1884 a very similar pest appeared in great numbers in the boot and shoe warehouses in St. Louis, United States of America. It attacked the boots in a very similar manner to our "leather beetle," and not only made its way into the warehouses, but also invaded the factories. They were locally known as "the dry hide beetle." This beetle is a much larger insect, belonging to the family Dermestidce. Professor Riley investigated the matter, and identified it as the "Toothed Dermestes," Dermestes vulpinus. (See the Entomologist's Report in the Annual Report of the United States Department of Agriculture, 1885.)

This beetle has a world-wide distribution. D. vulpinus and several other species are common in Australia, where they do a good deal of damage among flour, dried bacon and ham, while every year an immense number of sheepskins are destroyed by this weevil getting into them.

ReMEdies. - Where the Anobium has infested the trunks it would be best to put them in a tight chamber; the boots should be turned out of the boxes into a malt tank or other receptacle, and treated with bisulphide of carbon, kept in such a tight chamber so that the fumes of the carbon could not escape too rapidly, all larvæ and beetles would be destroyed. The boxes should be burnt, or. treated in the same manner, as they are sure to have eggs all over them, and if the eggs are left behind the pest will be sure to appear sooner or later, and the work will have to be done over again.

Care should be taken in the warehouse that all rubbish and waste is cleared out, and where the place is infested all such rubbish should be carefully burnt. 
Frequent examinations of the stock should be made if there is any sign of the beetles, for it is much easier to nip the pest in the bud than let it get a footing in the place. Notice should be sent to the factories from which the boots and shoes are imported, calling their attention to the existence of the insect in their goods, and with proper precautions on both sides the pest ought to be soon stamped out.

I desire to call attention to the fact that prompt measures should be taken to treat all trunks infested, for if these insects are allowed to breed in the cases, they are sure to creep out, lay their eggs in all parts, and get into the whole stock.

Description.-Anobium paniceum, Linn. The largest specimens (females) are $\frac{1}{6}$ of an inch in length, but many of the smaller (males) do not exceed $\frac{1}{8}$ of an inch.

Head, thorax, and elytra pitch brown, the under-side of the body, legs, and elytra covered with short pale-yellow hairs, which are very dense on the under-side. Anteunæ inserted close to the eyes, which are black and very prominent; 11-jointed; 1 st, thick subovate; $2 \mathrm{nd}$, shorter conical; $3-8$, very small ovate; 9-10, larger elongate, broadest at apex ; 11 th, elongate oval; the last three joints as long as the rest of antennæ. Head generally hidden under the thorax, jaws strong and armed with four obtuse teeth. Thorax broad, rounded in front, finely punctured. Elytra broad, rounded, marked with irregular punctured striæ. Legs robust, slightly swollen; tarsi, five-jointed.

Larva.-Soft cylindrical fleshy grub, with a scaly head, and the last joint of the abdomen large, not furnished with any appendage, and curved under the body. The jaws are strong and armed with four obtuse teeth.

When full grown the larvæ construct a cocoon of soft silky substance, mixed with the material upon which they have been feeding, and pupate at the end of their burrows.

WALTER W. FROGGATT,

$14 / 10 / 91$,

-Technological Museum, Sydney. 


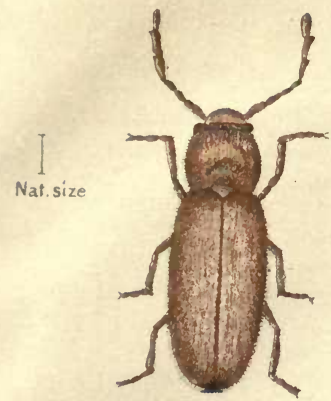

Fig. i.

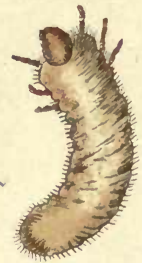

Fig. ii.

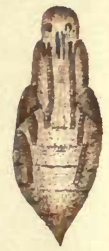

Fig. iii

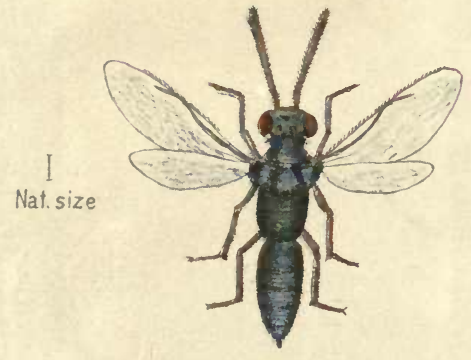

Fig. iv

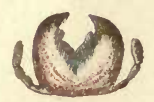

Fig. ia.

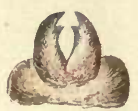

Fig. iia.

LIFE HISTORY OF ANOBIUM PANIGEUM.Lin.

Figi Perfect beetle (enlarged)

Fig. ii. Larva

Fig. iii. Pupa. Fig. ia Jaws of beetle Fig. iia Jaws of larva

Fig. iv. Parasitic Wasp (Fam. CHALCIDIDE) living onthe pupa of Anobium 


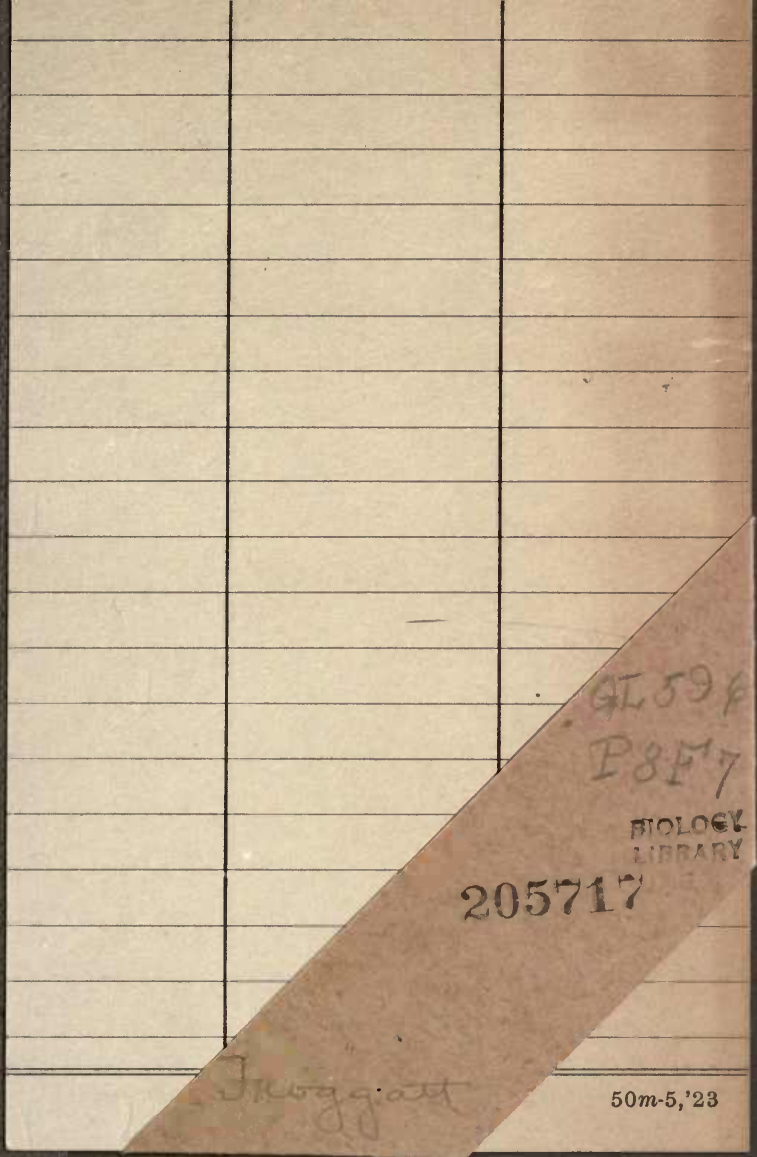


